\title{
FIXING THE SYSTEM: AN ANALYSIS OF ALTERNATIVE PROPOSALS FOR THE REFORM OF INTERNATIONAL TAX
}

\author{
Harry Grubert and Rosanne Altshuler
}

\begin{abstract}
We evaluate proposals for U.S. international tax reform including dividend exemption, full current inclusion, dividend exemption with an effective tax rate test and active business exception, dividend exemption with a per-country or overall minimum tax, and repeal of check-the-box. As alternatives to active business tests, we consider minimum taxes that allow expensing for real investment abroad. We evaluate reforms along many dimensions including the lockout effect, income shifting, the choice of location, and complexity. We find a per-country minimum tax with expensing has many advantages with respect to these margins. The simpler overall minimum tax is a serious alternative.
\end{abstract}

Keywords: multinational corporations, domestic-foreign tax differentials, income shifting, foreign-source income, corporate tax reform

JEL Codes: F23, H25, H32, H73

\section{INTRODUCTION}

Decent developments necessitate taking another look at alternative reforms of the NU.S. system for taxing cross-border income. Discontent with the U.S. worldwide system for taxing the international income of U.S. corporations has focused policy makers on possible reforms. Both Sen. Mike Enzi and House Ways and Means Chairman Dave Camp have released draft proposals of dividend exemption systems. Provisions that would tighten international tax laws have been part of every Obama Administration budget and the President's Economic Recovery Advisory Board (PERAB) has issued a report that includes an extensive discussion of international tax reform options (PERAB, 2010).'

\footnotetext{
1 On February 22, 2012, the White House and the U.S. Department of the Treasury released a joint report outlining a framework for business tax reform that includes, among other proposals, elimination of a number of business tax expenditures, a reduction in the corporate statutory tax rate to 28 percent, and a new minimum tax on foreign earnings apparently within the current worldwide system. This paper does not analyze that proposal.
}

Harry Grubert: U.S. Treasury Department, Office of Tax Analysis, Washington, DC, USA (harry.grubert@ treasury.gov)

Rosanne Altshuler: Department of Economics, Rutgers University, New Brunswick, NJ, USA (altshule@ rci.rutgers.edu) 
There is also additional evidence regarding the costs and benefits of the current U.S. system. One of the most important features of the current system in evaluating the incentives for foreign investment and the location of income is the burden of the repatriation tax on dividends. This burden includes both the U.S. residual tax on actual dividend repatriations which, due to effective tax planning by corporations, tends to be small, and more importantly the efficiency cost or "implicit" tax attributable to the avoidance of the repatriation tax. The unexpectedly large repatriations under the 2005 tax holiday suggest that this implicit cost of additional deferrals is larger than reflected in previous estimates.

Furthermore, both the international environment and U.S. tax laws have changed. The two other major industrial countries with worldwide systems, Japan and the United Kingdom, have converted to dividend exemption. In addition, both statutory and effective tax rates around the world have continued to decline relative to U.S. rates, sharpening the "competitiveness" issue (Devereux et al., 2009). ${ }^{2}$ The decline in foreign rates can also be expected to reduce the amount of excess foreign tax credits under the current system with important implications for company behavior.

The reduction in the frequency of excess credit positions will gain added impetus by the enactment in 2010 of the new foreign tax credit anti-splitter rules. In the past, multinational corporations (MNCs) have been able to use various devices such as hybrid entities and foreign partnerships to separate the foreign tax from the income that gave rise to it. They have thereby been able to increase the amount of foreign tax credits claimed relative to the income being repatriated. The new Section 909 in the Internal Revenue Code limits this type of credit manipulation. The resulting decline in excess foreign tax credits will substantially revise the comparison of the current system versus its alternatives.

Taking these developments into account, we evaluate proposals for reform of the U.S. tax system for taxing cross-border income including dividend exemption, full inclusion, and a Japanese-type version of dividend exemption with an effective tax rate test and an exception for active business. We also study versions of a cividend exemption system that include either country-by-country or overall minimum taxes with no active business exceptions. As an alternative to an active business test, we consider a current deduction against the minimum tax for real investment in the location as an option. Given the importance of the check-the-box rules to tax planning, we also include their repeal as one of the options for reform within current law.

2 Devereux et al. (2009) find that average effective tax rates across all European Union countries fell almost 8 percentage points, from 29.3 to 21.5 percent, over the period 1998-2009. The authors report an average effective tax rate for the United States of 37.4 percent in 2009 and a rate of 38.3 percent in 2005 (they did not calculate U.S. effective tax rates for years prior to 2005). Over the same 1998-2009 period, the average effective statutory rate (including local statutory rates) for all European Union countries fell almost 10 percentage points from 33.5 percent to 23.8 percent while the U.S. effective statutory rate fell less than 2 percentage points from 39.8 percent to 37.4 percent. The decrease in the U.S. rate was entirely due to reductions in statutory tax rates at the state level since the federal statutory rate remained at 35 percent throughout this time period. 
To compare dividend exemption proposals with current law, we reevaluate the burden of the current repatriation tax taking the response to the 2005 tax holiday into account. The implicit cost of avoiding repatriation turns out to be higher than found in previous estimates and increases as deferrals accumulate abroad. This finding has significant implications for our analysis.

We evaluate the proposals using a number of criteria. We examine the impact of the proposals on the lockout effect, changes in the incentives to shift income, the distortion of investment incentives and whether the reform is consistent with a more efficient allocation of worldwide capital, revenue, complexity, tax planning incentives beyond income shifting, and incentives to expatriate, which are all different components of any change in efficiency. We simulate effective tax rates for low and high-tax investments abroad to show how the effects of the various alternatives and illustrate their consequences. To highlight how the various systems affect income shifting alternatives, we consider investments that produce high tech goods using U.S.-developed intangible assets.

The analysis suggests that the per-country minimum tax with expensing has many advantages compared to the other schemes. The per-country minimum tax we propose offsets (at least in part) the increased incentives for income shifting under a pure dividend exemption system. Unlike the Japanese type dividend exemption alternative considered in this paper, under the minimum tax option there is no cliff in which the income is subject to the full home country rate if it fails the minimum tax and active business test. The company has more of an incentive to lower foreign taxes and will often prefer paying the U.S. minimum tax to paying a higher foreign tax. The minimum tax also seems more advantageous than the repeal of check-the-box. It is more effective in discouraging income shifting and raising the effective tax rate in low-tax countries. Further, repeal of check-the-box would result in companies unwinding hybrids in tax havens and sheltering income in countries with rates below the U.S. rate. Under the minimum tax, the U.S. would gencrate revenue on income sheltered in havens abroad.

Finally, the per-country minimum tax with expensing for real investment is better than full inclusion in tailoring companies' effective tax rates to their competitive position abroad. No U.S. tax burden will fall on companies that earn just a normal return abroad, appropriately preserving capital import neutrality (CIN). The minimum tax with expensing is basically a tax on large excess returns in low-tax locations, cases in which the company probably has less intense foreign competition. The minimum tax combines the advantages of the extreme alternatives, dividend exemption and full inclusion, and has fewer of their shortcomings.

Our comparison of overall and per-country minimum taxes suggests that the overall version deserves serious consideration. While it is not as successful as the per-country minimum tax in targeting tax haven income, it is a substantial move in that direction and is much simpler.

The paper is organized as follows. We start by briefly discussing problems with the traditional criteria used to evaluate international tax proposals. We stress that the optimal tax on foreign income is a "second best" problem and that alternatives should be judged based on whether they move the system towards the second best answer. 
We then highlight problems with the current U.S. worldwide tax with deferral system and describe both the proposals we analyze and criteria we use to judge the alternative proposals. To evaluate reforms against current law it is necessary to reevaluate the efficiency cost of accumulating deferrals. After presenting new estimates of the implicit burden of deferrals, we present the results of our effective tax rate simulations. This analysis is followed by a discussion of the revenue consequences of the current system and the various alternatives, a comparison of the overall versus the per-country minimum tax, an analysis of the incentives to expatriate under the various alternatives, and an evaluation of how the reform alternatives differ in terms of complexity. Before concluding we discuss two reform alternatives that have been advanced as possible fixes to our current system: formulary apportionment (with specific emphasis on a sales apportionment factor) and a destination-based income tax.

\section{ALTERNATIVE CRITERIA FOR FOREIGN INVESTMENT}

There is an extensive literature on the alternative standards that should guide the process of evaluating international tax reform proposals including Capital Export Neutrality (CEN), Capital Import Neutrality (CIN), and, more recently, Capital Ownership Neutrality (CON). However, as indicated in Grubert and Altshuler (2008), the usual evaluation of reforms relative to these norms is not very helpful because each proposed standard is based on very special assumptions. Furthermore, none of the standards address the most important issues in designing an international tax system, such as the taxation of excess returns and royalties, income shifting, and the allocation of parent expenses to foreign income.

The optimal tax on foreign income is in general a second best problem because there are existing foreign and domestic taxes. ${ }^{3}$ The second best solution depends on which investments a potential foreign investment competes with, those in high-tax jurisdictions abroad and in the United States, or those in low-tax locations. The solution also depends on the sources of additional capital to the firm, which can be from additional saving or at the expense of either other domestic investments in the corporate or noncorporate sectors or portfolio investments abroad. It is difficult to have a single rule that will fit all cases. Some investments are highly mobile, serving a worldwide market, with many possible alternative locations. Others are more closely tied to a given location because of the importance of being close to customers or to a source of raw materials. Some investments compete with U.S. production while others compete with low-tax production abroad. None of the standards will be appropriate in all cases, and it is not feasible to design a policy with different rules for different cases.

It may, however, be possible to design relatively simple rules that move policy towards the second best solution. One of the alternatives we evaluate is a minimum tax on foreign income, on either a country-by-country or overall basis, with a current deduction for real investment against the U.S. minimum taxable base in the location. The minimum

3 Grubert and Mutti (1995) discuss the general second best rule. 
tax therefore applies only to excess returns in the foreign location. Investments with large excess returns probably do not have very close foreign competitors, so imposing a minimum tax is not likely to put them at a competitive disadvantage abroad. Also, some of the tax would be on economic rents and thus be non-distortionary (ignoring any possible expatriation responses). The investment would take place even with the minimum tax, which just acts to reduce the tax considerations in the choice of where it is located.

On the other hand, companies that make basic real investments that do not earn much more than a normal return probably have more intense foreign competition. Imposing a U.S. tax on such companies could put them at a competitive disadvantage even if they were more efficient than their rivals. A minimum tax with expensing therefore has the virtue of moving the system towards CEN for foreign investments with large excess returns and little competition, and towards CIN for more basic real investments that compete with close rivals in foreign locations for normal returns.

It should be noted that designing a set of international tax rules is mainly a question of determining how excess returns attributable to U.S. developed intellectual property are taxed. If the investment simply involves standard real capital that earns normal returns like an aircraft or a ship, it can be leased from foreign investors since the rental price will not reflect any U.S. tax. A company can therefore already exempt capital that earns the normal return from U.S. tax by leasing the capital.

\section{PROBLEMS WITH THE CURRENT WORLDWIDE SYSTEM}

The present system raises little revenue, is complicated, creates incentives for aggressive income shifting, and interferes with companies' efficient use of capital as they try to avoid the dividend repatriation tax. It is hard to argue that the current system is based on any coherent concept of how an optimal system should be designed. Consider the following problems:

1. Income shifting. The evidence on income shifting under the current U.S. system is extensive, and the problem seems to be getting worse, in part because of the generous tax planning opportunities opened up by the check-the-box rules enacted in 1997 (Grubert, 2012). As evident in the effective tax rate simulations presented below, this aggressive tax planning distorts investment decisions by magnifying the benefits of low-tax locations.

2. The lockout effect attributable to both actual and "implicit" tax costs. U.S. companies use various techniques for avoiding the repatriation tax, such as having the U.S. parent borrow using accumulated financial assets abroad as implicit collateral (Altshuler and Grubert, 2002). But these repatriation avoidance schemes come at a cost, such as a ballooning balance sheet that raises the company's cost of capital. The avoidance of the repatriation tax may also induce U.S. companies to acquire foreign companies in part because of the cheap source of locked out capital available. 
3. Complexity. The current system requires extensive calculations and adjustments involving foreign tax credits, allocated expenses, etc.

4. Competitiveness. While the current system provides many advantages to a low-tax foreign location, there may be cases where the potential repatriation tax and other rules discourage real investments that are consistent with an efficient worldwide allocation of capital. This may be the case when U.S. companies may not expect to earn much more than the normal cost of capital. Any new system should not prejudice productive real investments abroad.

The main question in this paper is whether improvements can be made in all of these areas or if the goals are in conflict. Must eliminating the lockout of foreign earnings exacerbate incentives for income shifting? Can income shifting be limited without an unnecessary burden on productive foreign investment?

\section{PROPOSALS FOR REFORM}

The baseline for our analysis is the current worldwide system but with a 30 percent corporate rate. There seems to be a growing consensus that the United States should reduce its corporate statutory rate in response to the dramatic and continuing decline in corporate statutory rates abroad. Accordingly, it seems appropriate to consider the current system with a lower rate. We analyze five proposals for reform against this baseline:

1. Full inclusion. The worldwide system is retained and the deferral privilege for active business income is repealed. ${ }^{4}$

2. Dividend exemption. Dividends derived from active business income can be repatriated free from U.S. tax. Royalties and other payments deductible abroad and export sales income are fully taxed. We consider a system in which there are no allocations of parent overhead expenses to exempt foreign income. ${ }^{5}$ Capital gains from the sale of an active foreign asset would be exempt on the grounds that the price is based on future dividends. We assume that passive income and other income now taxed currently under subpart $F$ would continue to be subject to current tax.

3. Dividend exemption with a version of the Japanese effective tax rate test. This is similar to one of the anti-base-erosion alternatives in Chairman Camp's dividend exemption proposal (U.S. House Ways and Means Committee, 2011). If the country effective tax rate is below the threshold -20 percent in the Japanese plan and 15 in the dividend exemption option we consider - the income is currently included in U.S. taxable income and is subject to the full

\footnotetext{
4 This can be done in two ways. One is the "Branch Method" that treats each subsidiary as a branch of the parent. Losses in some CFCs can therefore offset positive income elsewhere including in the parent. An alternative is the "Subpart F Method" in which only positive income is included in the worldwide base.

$s$ Domestic expenses directly allocable to exempt foreign income are not deductible from the U.S. tax base.
} 
corporate rate. But the subsidiary's income can escape inclusion if it passes an active business test. As a result, the taxation of the subsidiary's income faces a cliff if it doesn't pass the test. Companies therefore will not shift income to a pure tax haven as they do now with check-the-box planning.

4a. A country-by-country minimum tax of 15 percent on active income with a credit for the effective foreign tax rate up to the 15 percent threshold. As in plan 3 , effective tax rates are computed for income in each jurisdiction, so the income and tax in disregarded entities under check-the-box are placed in the location in which they are taxed and not consolidated with its Controlled Foreign Corporation (CFC) owner. Operations with losses within a country are combined with those without losses. The country tax base is Earnings and Profits (E\&P) less intercompany dividends because that income has already been taxed in other jurisdictions. ${ }^{6}$ The base subject to the minimum tax also excludes income fully taxed under subpart F. Payments received that are deductible elsewhere such as royalties and interest are included in the base. The effective tax rate is the ratio of foreign taxes paid to this net E\&P income base. ${ }^{7}$ Dividends both from countries subject to the minimum tax and those above the minimum are fully exempt, including dividends from previously taxed income. There is no active business exception to the minimum tax and no allocations of parent overhead expense to foreign income. As under dividend exemption, royalties, interest, and export sales income are fully taxed at the U.S. rate. ${ }^{8}$ Capital gains on the sale of an operating foreign asset are taxed at a 15 percent rate net of a credit for foreign taxes.

4b. The same as $4 \mathrm{a}$ but the company can deduct real investment in the country from the minimum tax base. Therefore there is no U.S. tax on the company's normal return abroad, the rate with which it discounts cash flows from real investments. Only the excess return is taxed at the U.S. rate and even then only in part because there is still some incentive for income shifting from the United States. In this option, the E\&P of the foreign entity in a location would first be calculated in the normal way and its effective tax rate would be based on that E\&P. If the effective tax rate is below 15 percent, minimum tax would be due but the new investment could be deducted from the tentative taxable base. In future years the process would be repeated for the investment, except now the taxable base would be increased by normal E\&P depreciation to recapture the initial expensing.

6 Earnings and Profits is defined in the Internal Revenue Code and regulations and is close to book or economic income. It is not local taxable income.

7 The precise definition of E\&P is net of foreign taxes paid, so foreign taxes are added to the denominator in the effective tax ratio to get pre-tax income. Similarly, foreign taxes are added to E\&P to construct the taxable base.

8 It is not quite correct to characterize the minimum tax as the equivalent of eliminating deferral but taxing the income at a lower rate. As in any dividend exemption scheme, royalties and interest are fully taxable and there is no flow-over of excess credits to shield them. There is no cross-country crediting. 
4c. The same as $4 \mathrm{a}$ but with a minimum tax calculated on an overall instead of country-by-country basis. A company would be subject to a tax of 15 percent on active foreign income with a credit for the company's overall effective foreign tax rate up to the 15 percent threshold. The company's effective foreign tax rate is calculated by taking the ratio of total foreign taxes to total foreign E\&P net of dividends received.

4d. As in the case of the country-by-country minimum tax, we also consider an option that allows a deduction from the tax base for all real investment abroad.

5. Repeal of check-the-box within current law. Under repeal, most hybrids would be unwound because firms would prefer to pay the lower foreign tax rather than the U.S. tax that would be due under subpart F. The result would be a return to pre-1997 income shifting, and would in part address the problem of "stateless income" that has been referenced in the literature (Kleinbard, 2011).

\section{A. The Operation of the Per-Country Minimum Tax}

As indicated above, the minimum tax is imposed on a country-by-country basis, not a CFC-by-CFC basis. If the company uses check-the-box to pay interest and royalties from one entity in the consolidated CFC to another, the interest and royalties are deductible from the payor and are assigned to the country in which they are subject to tax, based on tax residence. Thus, for example, an entity incorporated in Ireland that is resident in Bermuda under the Irish place of management rule has its income assigned to Bermuda. Wherever the foreign income is, it bears a (U.S. plus foreign) tax of at least 15 percent. In order to achieve this result, it is necessary to prevent income being deductible in one location but exempt in the receiving entity. Thus, hybrid securities could not be used to strip E\&P from a tax haven with the payment exempt under the receiving country's territorial regime. ${ }^{9}$

In calculating the effective tax rate in any location, using a single year could lead to erratic perturbations over time because of the timing of deductions and credits, losses, etc. We therefore propose using a five-year average of foreign taxes paid in relation to E\&P. Taxes and E\&P for the current and past four years would be pooled for the purpose of the calculation. Then to calculate the tentative U.S. tax liability in the current tax year, the excess of 15 percent above the average foreign tax rate is multiplied by the five-year average of E\&P. That is, the five-year average effective tax rate and the income it applies to should be based on the same pool of income. Otherwise, there would be opportunities for manipulating the timing of income and deductions to reduce U.S. tax.

9 Companies are now required to attach a Form 8858 for each of the disregarded entities (DREs) owned by the CFC for which the Form 5471 is being filed. The Form 8858 gives the DRE's Earnings and Profits, the country under whose laws it is organized, and the country in which its principal business activity is conducted. 
In the expensing variations, current real investment can be deducted from the taxable E\&P base. But expensing does not change the relevant average foreign effective tax rate for the purpose of calculating the stable residual U.S. tax rate. The foreign effective tax rate, which determines the residual U.S. tax rate, is unaffected by the expensing.

Smoothing annual variations in foreign effective tax rates reduces the possibility that a given subsidiary will move above and below the 15 percent threshold over time. Another important reason for averaging is that it helps to achieve the exemption of the normal return in the expensing option because it increases the likelihood that the tax rate that applies to the deduction is the same as the tax rate that applies to the subsequent income.

The expensing under the minimum tax is intended to make the forward-looking U.S. effective tax rate (ETR) on the normal return to investment zero while the forward looking ETR on the excess return bears a total tax, including both the foreign and U.S. components, of at least 15 percentage points. In the smoothing of effective tax rates and income that we propose, the deduction for investment is always for current year investment, not a five-year average, in order to maintain the zero forward looking U.S. effective tax rate on the normal return. A delay in the deduction through averaging would fail to accomplish this objective.

Consider the case of a subsidiary in a country with a 5 percent effective tax rate. The U.S. tax is therefore $(0.15-0.05)$ or 10 percent of the taxable base. The subsidiary's current pre-tax E\&P is 200 per year. The tentative U.S. tax before expensing would therefore be $(0.15-0.05)^{*} 200=20$. It considers an investment of 100 in the current year. ${ }^{10}$ This would be deductible from the U.S. taxable base and the current tax would therefore become $(0.15-0.05) *(200-100)=10$.

The company expects to earn 30 each year on the investment but the normal return, its cost of capital, is only 10 or 10 percent. Its annual excess return is therefore 20 . The present discounted value of the excess return is $20 / 0.1=200$. The present value of the U.S. tax on the return from the investment is $\left(30^{*} 0.1\right) / 0.1-10$ of tax that was saved from the current expensing, i.e., $30-10=20$. The total effective tax rate on the expected excess return is 15 percent, the 10 percent of U.S. tax plus the 5 percent of foreign tax. "If the expected return had been only 10 percent, the normal level, the expected U.S. tax rate on the investment would be zero. Of course the foreign 5 percent tax would remain.

One specific issue is what to do with withholding taxes on dividends. They cannot be linked to any particular location's income because of payments up the tiers of affiliates. Dividends also vary from year to year, so attributing them to a particular location would be inconsistent with the goal of stable per-country effective tax rates. One

${ }^{10}$ We assume for simplicity that the capital does not depreciate.

"In fact, the marginal foreign tax rate on the excess return may not be exactly equal to the effective tax rate. The relevant statutory rate, which can be different from the effective tax rate, may apply. But the company's own effective rate, the ratio of actual taxes paid to economic income, is the best feasible approximation. The relevant statutory rate may be virtually impossible to determine because of tax holidays, patent boxes, state and regional differences, negotiated rates, etc. 
solution would be to credit withholding taxes against any combined U.S. tentative tax liability at the parent level.

Another issue that arises is whether assets beyond tangible capital can be expensed. This issue is of particular concern for financial businesses. Consideration might be given to net of debt active business assets if they can be precisely defined.

\section{B. The Operation of the Overall Minimum Tax}

The overall minimum tax would operate similarly to the per-country minimum tax. The overall foreign tax rate for the purpose of the minimum tax would be calculated using a five-year average of foreign taxes paid in relation to E\&P. Since the overall effective rate is likely to be less noisy than effective tax rates calculated at the country level, the averaging could be over a shorter period.

\section{The One-Time Tax when Dividends are Exempt}

We assume there would be a one-time tax on the stock of pre-effective date untaxed deferrals in all the proposals in which dividends are exempt. Under both the countryby-country and overall minimum tax options with expensing, the one-time tax on preeffective date untaxed deferrals takes a consistent form. Instead of applying to all untaxed deferred income, tangible capital can be deducted from total accumulated deferrals for the purposes of the tax. Only the "trapped cash" that gets the greatest benefits from the new regime is taxed. An alternative with the same goal would be to simply tax the entity's portfolio investments to the extent that they are less than total deferrals. They are the assets that yield income in the passive basket.

\section{Acquisitions under the Expensing Versions of the Minimum Tax}

A tax system should not distinguish between the treatment of a greenfield investment and an acquisition of a similar operating asset. Investing in a plant should not have a tax treatment different from acquiring a company that owns a similar plant. Therefore, some allowance should be given for assets obtained by acquisition. An annual deduction against the minimum tax base equal to the normal return on the market value of tangible assets acquired would be appropriate. Indeed, it seems appropriate to include all active operating assets acquired, including intangible assets, in the applicable base for the purposes of the deduction. ${ }^{12}$ (In the case of the greenfield investment, most of the intangible investments like start-up costs and market development are expensed.)

\footnotetext{
12 An annual allowance rather than an immediate deduction for the entire acquisition price is suggested to avoid large variations in taxable income over time. However, it does require measuring the normal return so a system of immediate expensing with carry-forwards might be considered.
} 
We note that the treatment of acquisitions would be simpler under the overall minimum tax than under the per-country tax as it would not be necessary to allocate the assets in a foreign acquisition to particular locations in the former. The main objective of the minimum tax is to tax the excess return attributable to intangible assets developed by the parent, not the normal return on assets acquired. ${ }^{13}$

Taxing the excess return would not put U.S. companies at a competitive disadvantage in making foreign investments and acquisitions. They will still make the investments if they are more efficient than their rivals. If the intangible that is the source of the excess return is mobile, such as a patent used to produce a good sold on the worldwide market, the tax may just change where the investment is made. The choice of location will be less influenced by tax considerations than under the current system.

It might seem inappropriate to attribute all of the excess return to the U.S. parent as some contribution might be made by researchers and marketers abroad. But any excess return is taxed at most at 50 percent the normal U.S. corporate rate (assuming a U.S. statutory rate of 30 percent and minimum tax of 15 percent), which is equivalent to assuming that half of the excess return is the result of the parent's activities. That is probably a substantial underestimate because, for example, a disproportionate amount of U.S. company R\&D is still performed in the United States (Yorgason, 2007). If a foreign company acquired by the parent has valuable intangibles, that would be reflected in the acquisition price for which an allowance against the minimum tax is given.

The annual allowance for the value of acquired assets would only be applied to the equity invested by the parent. If some of the acquisition debt is on the parent's books, it should be allocated to the new acquisition.

Another issue related to acquisitions concerns the treatment of assets existing at the time of the effective date of the new system. An alternative is to not give a deduction for the capital against the one-time tax and instead give an allowance for the initial stock of capital. If firms were to receive an allowance for assets obtained in acquisitions as discussed above, they should receive an allowance for the initial stock of capital in the transition to the new system.

\section{CRITERIA FOR JUDGING THE ALTERNATIVE SCHEMES}

The question we are interested in evaluating is which of the proposals gets closest to fulfilling the goals of efficiency and simplicity. We take a broad view of efficiency to include the losses from income shifting attributable to tax planning costs and the

${ }_{13}$ The normal return would apply over time to the depreciated real assets acquired. If the capital is replaced it can be currently expensed. The depreciation each year would be the amount specified by the E\&P rules for the purposes of determining the U.S. taxable income base. Similar to the Allowance for Corporate Equity (ACE), this approach has the desirable property that any accelerated depreciation is self-correcting. If the depreciation deduction is increased, any current tax benefit is equal in present value to the future losses from the allowance applying to a smaller capital base. 
distortions in investment incentives. We consider the issues listed below in our analysis of the desirability of the alternative schemes:

1. The lockout effect. All of the proposals eliminate the actual and implicit burden of the dividend repatriation tax. Because of the large implicit burden from large growing accumulations, this is a source of a substantial efficiency gain.

2. Changes in the incentives to shift income. These incentives disappear completely under full inclusion except for the companies that remain in excess credit. On the other hand, they expand under dividend exemption because of the elimination of the repatriation tax. The question will be whether the minimum tax is sufficient to reduce shifting incentives compared to the current system despite the elimination of the lockout burden. How close will the effective tax rate in a low-tax location get to the undistorted (by income shifting) local rate?

3. Is the pattern of the changes in effective tax rates consistent with a more efficient worldwide allocation of capital? This means reducing investment distortions due to income shifting opportunities but also not imposing burdensome U.S. tax when a company faces intense competition in foreign locations.

4. Revenue. Although we generally adopt the worldwide efficiency criterion, for the same worldwide revenue we would prefer it be paid to the Treasury rather than go into foreign coffers. We assume that the options would be part of revenue neutral, comprehensive tax reform that lowers the U.S. corporate tax rate. Which country gets the revenue depends on the plan's incentives to lower foreign tax. Under full inclusion, the company has no incentive to lower foreign taxes unless it has excess foreign tax credits. In contrast, the company has the incentive to lower any foreign tax under dividend exemption. Under the per-country minimum tax (and under the overall minimum tax if the company is above the threshold), it has the incentive to lower any foreign tax that is above a 15 percent rate. Under the Japanese style dividend exemption cliff, companies have an incentive to be above the 15 percent threshold as long as it is less than the home country full inclusion rate.

5. Matching benefits and costs. For example, are the companies that get a large benefit from the freeing of their cash from the lockout effect the ones who have to pay additional tax?

6. Complexity. This includes credit planning and repatriation tax avoidance, expense allocations to foreign income, active business tests, effective foreign tax rate calculations, etc.

7. Incentives for additional tax planning such as switching from taxable royalties to exempt equity under dividend exemption.

8. Changes in the incentives to expatriate through inversions or mergers with foreign companies. Any increase in the U.S. tax on foreign income would tend to increase the benefits of expatriation, but this may be offset somewhat by elimination of the lockout effect and reduced complexity. 


\section{THE EFFICIENCY COST OF ACCUMULATING DEFERRALS}

The efficiency cost to companies of avoiding the repatriation tax on dividends is important in evaluating any shift from the current worldwide system to a system in which U.S. tax liabilities do not depend on foreign dividends. These implicit costs attributable to ballooning parent debt and foregone domestic opportunities, etc., may be much larger than the explicit tax costs resulting from actual distributions. These costs may vary over the life cycle of a company's foreign operations so their impact on the effective tax rates on foreign investment will depend on whether the foreign operation is relatively new or relatively mature with a large stock of accumulated untaxed deferrals.

Estimates of the implicit burden of avoiding the residual U.S. tax on foreign dividends have tended to suggest a rather modest cost. Studies by Grubert and Mutti (2001) and Desai, Foley, and Hines (2001) report efficiency costs of about 1 percent of foreign income. Both used a similar methodology, calculating the deadweight loss attributable to the repatriation tax for a given investment based on CFC dividend repatriation equations. Grubert and Mutti concluded that in countries with effective tax rates below 10 percent the efficiency loss amounted to 1.7 percent of income. Adding the residual tax on actual dividends resulted in a combined cost of the repatriation tax of about 3 percent for a given investment. More recently, Grubert and Altshuler (2008) added a measure of potential accumulations of deferred income to a repatriation equation and concluded that the efficiency cost increases as the potential stock of deferrals increase. Indeed, the deterrent effect of the residual tax on repatriations appeared to lose its impact after 25 years of potential accumulations. But on the basis of the distribution of CFC ages, they concluded that the average efficiency cost was still about 1 percent of 2002 income. They, however, did not project what the impact of continuing accumulations would be in the future.

Some studies of residence relocations and cross-border mergers and acquisitions have found a very large impact of the dividend repatriation tax, including Huizinga and Voget (2009), Voget (2011), and Arulampalam, Devereux, and Liberini (2012). These studies are based largely on non-U.S. companies headquartered in countries such as the United Kingdom that used to have worldwide systems. But these countries did not seem to have anything comparable to Section 956 , which subjects subsidiary loans to and investments into the United States to current taxation. Without this type of rule, the subsidiary could get cash to the parent free from tax, so it is surprising to find that the potential repatriation tax has much impact. Therefore, it is only for U.S. MNCs that one might expect to see a significant impact.

Here we look at the issue again. One reason to do so is the unexpectedly large response to the 2005 repatriation tax holiday in which companies were able to bring back dividends in excess of a historical base subject to a 5.25 percent tax net of a scaled down credit. The companies who took advantage of the tax holiday paid an average of 3.6 percent on their repatriations (Redmiles, 2008). They were willing to pay this amount to avoid actual or implicit future costs of at least this amount in terms of present value. 
We go into the details of this analysis in Appendix A. ${ }^{14}$ We develop a model that incorporates the assumption that avoiding the repatriation tax is not costless, and further that the marginal cost of additional deferrals rises as the stock of accumulations grows relative to current earnings. The empirical analysis of repatriations under the 2005 tax holiday confirms these hypotheses. The repatriation tax holiday evidence is then used to calibrate the marginal cost of repatriation tax avoidance and how it evolves as deferrals accumulate.

The Tobit regressions presented and discussed in Appendix A use 2004 data from U.S. Treasury tax files on companies' tax holiday repatriations and accumulated deferrals before the holiday to identify the factors that increase the marginal costs of avoiding the repatriation tax. Alternative specifications are used. One examines the relationship between the share of accumulated deferrals that were repatriated and the size of accumulations relative to current income. Another specification scales variables by current sales and related repatriations to the size of the stock of deferrals. In that specification the square of the stock of deferrals was also added as an independent variable to test for the possibility that an increasing stock motivated a disproportionate increase in repatriations. Other independent variables include parent R\&D intensity, the company's foreign profit margin on sales, the amount of accumulated income previously taxed under the CFC rules, and the ratio of tangible capital to sales.

The results provide strong support for the hypothesis that the marginal cost of deferring income rises as the accumulated stock of deferrals increase. ${ }^{15}$ The share of accumulated deferrals repatriated in 2004 rose when the accumulated stock was higher in relation to current income. A higher stock of deferrals resulted in a disproportionate rise in tax holiday repatriations. In addition, parent R\&D intensity and the profit margin abroad had a very significant impact in increasing tax holiday repatriations. The highly profitable, high tech subsidiaries seemed to have much fewer profitable opportunities for reinvesting their income.

A model presented in Appendix A, which incorporates the rising marginal cost of deferral findings, is used to illustrate a company's repatriation decision under a permanent repatriation tax and under a temporary reduction in the repatriation tax. Under a permanent repatriation tax, the company begins to repatriate when the marginal cost of permanently retaining another dollar rises to equal the repatriation tax. In contrast, consider a temporary tax holiday tax rate after credits of 5 percent. The company will repatriate income beyond the point at which the marginal cost of further deferrals is equal to 5 percentage points. The reason is that an additional dollar of tax holiday repatriations

\footnotetext{
14 See Appendix A, http://econweb.rutgers.edu/altshule/Technical\%20appendices.h:m.

is If the marginal cost of any year's additional deferrals were constant, contrary to our hypothesis, the estimate of the implicit cost of deferrals could be higher. This would imply that any repatriation under the tax holiday would have had an implicit cost above the holiday tax rate. Under the rising cost hypothesis, this is not the case because of the "fresh start" benefits that arise from delaying the onset of future high costs. Immediately after the tax holiday repatriations the marginal cost of deferrals is low, below the tax holiday tax rate, but may rise significantly as time passes.
} 
saves not the constant cost of another dollar of permanent accumulations at that point but the rising marginal costs of greater accumulations as the deferral process begins again under the higher, normal repatriation tax. The tax holiday gives the subsidiary a "fresh start" so that after the tax holiday it can begin deferring income with a low stock of deferrals and much lower marginal costs. It will repatriate a greater amount if the marginal cost of deferrals rises more steeply as the stock of deferrals grows.

We use the tax holiday evidence to calibrate the optimal conditions for repatriating under a tax holiday. The calibration indicates the extent to which the marginal cost of deferring income in a low-tax profitable operation abroad rises as the stock of deferrals grows. As expected, the marginal cost of deferral is very low immediately after the tax holiday repatriations, but after 10 years, that is, in the year 2015 , it rises to about 7 percentage points. This includes both the cost of actual repatriations that companies expected to make as they looked forward 10 years and the implicit cost of continued repatriation tax avoidance. Actual repatriations probably account for a small share of the total 7 percent cost. Accumulations have continued at a high rate. BEA data indicate that total retained earnings of nonbank affiliates abroad at the end of 2010 were almost double the amount at the end of 2004, even after the large tax holiday repatriations in 2005 and the severe recession. Thus in the effective tax rate simulations that follow, we are conservative in assuming a cost of 5 percentage points for a mature highly profitable, R\&D intensive company. ${ }^{16}$

\section{EFFECTIVE TAX RATE SIMULATIONS}

\section{A. The Model}

Simulations are useful in showing how the various alternatives operate and their consequences. Because of the evidence of the importance of income shifting, we emphasize how the alternative systems affect shifting incentives and how this translates into changes in effective tax rates. ${ }^{17}$ The simulations therefore show the effect of different policies on several important behavioral margins. These include the investment location decision, the income shifting decision, and the repatriation planning decision. In addition, they can indicate the change in companies' incentives to expatriate in terms of any increase in tax liabilities net of reduced company costs for income shifting and repatriation planning.

In analyzing income shifting, it is important to distinguish between two types of shifting, that is, income shifting before the introduction of check-the-box and income shifting after check-the-box. Before the introduction of check-the-box, stripping income to a tax haven through intercompany payments like interest and royalties was limited by

\footnotetext{
${ }^{16}$ It might be claimed that companies expected another repatriation tax holiday sometime in a few years. If so, they repatriated less than our model would indicate, causing us to underestimate the marginal cost of additional deferrals.

${ }^{17}$ Clausing (2009), for example, provides an estimate of U.S. corporate revenue lost to income shifting.
} 
the subpart $F$ rules. It was therefore necessary to invest in real operations in a low-tax country in order to locate income there. Moreover, greater investment would facilitate greater income shifting because of a larger volume of intercompany transactions. After the introduction of check-the-box this link between real investment and the location of income became much weaker (Grubert 2012 and Kleinbard 2011). But the two types of income shifting can reinforce each other. The use of a tax haven can make the tax rate on an operation in a low-tax country even lower and can effectively convert a high-tax country into a relatively low-tax one.

The effective tax rates for various policy scenarios are presented in Table 1. We assume three countries: the United States, a high-tax foreign country, and a low-tax country in which real operations can be located. A new discrete investment of a given size is considered in each location. Each investment is considered by itself. In addition to the high- and low-tax countries, there is also a pure tax haven where income can be shifted if check-the-box can be used. In each country depreciation for tax purposes is equal to economic depreciation. There is no third party debt. Therefore, in the absence of income shifting, the country effective tax rate is equal to the statutory rate. For the purpose of the simulations, the statutory tax rate is equal to 30 percent in the United States, 5 percent in the low-tax country, and 25 percent in the high-tax country (and zero in the tax haven). The current law effective tax rates take the interest allocation rules into account. These rules bind only for firms with excess foreign tax credits.

We assume that the subsidiary in the low-tax country produces a high tech good using a U.S. developed intangible asset. It therefore earns an excess return before paying royalties to the parent for the contribution of its intellectual property. The subsidiary's own contribution to the company's worldwide profits is just the normal return to its capital. The difference in tax rates creates an incentive to underpay the royalty to the U.S. parent but the underpayment is not costless. Tax planning takes resources and there is also the risk of penalties after audit. We assume that, in this pre-check-the-box type of tax planning, the cost of the income shifting or underpayment of royalties is a quadratic function of the amount shifted relative to the amount of real capital. The parameter in the function is calibrated to be consistent with observed profit margins in low-tax countries under current law.

Income shifting alters the effective tax rate on new investment because added investment in a location increases the opportunity for additional income shifting. There are more transactions with other related parties and greater ability to use intangibles developed in the United States. In addition, if hybrid entities in tax havens can be used, investment incentives are the same as if the host countries for operating subsidiaries had lowered their tax rates. Income shifting will have an effect on investment in both highand low-tax countries. Additional investment in the high-tax country benefits because some of its income can be shifted to the low-tax country or to tax havens.

The subsidiary in the high-tax foreign country produces a routine component and earns a normal return in the absence of profit shifting. It has an incentive to shift income to the low-tax country but the ability to engage in that type of shifting is much more 


\section{Table 1}

Effective Tax Rate Simulations

\begin{tabular}{|c|c|c|}
\hline & $\begin{array}{c}\text { Before } \\
\text { Check-the-box }\end{array}$ & $\begin{array}{c}\text { After } \\
\text { Check-the-box }\end{array}$ \\
\hline Low-tax investment (statutory rate $=0.05$ ) & . & \\
\hline Current law & -0.182 & -0.236 \\
\hline Full inclusion & 0.300 & 0.300 \\
\hline Dividend exemption & -0.236 & -0.295 \\
\hline Japan minimum tax & & -0.236 \\
\hline Per-country minimum tax & & 0.056 \\
\hline Per-country minimum tax with expensing & & -0.044 \\
\hline $\begin{array}{l}\text { Overall minimum tax for parent with foreign } \\
\text { ETR }>15 \%\end{array}$ & & -0.295 \\
\hline $\begin{array}{l}\text { Overall minimum tax for parent with foreign } \\
\text { ETR }<15 \%\end{array}$ & & 0.060 \\
\hline $\begin{array}{l}\text { Overall minimum tax for parent with foreign } \\
\text { ETR }>15 \% \text { with expensing }\end{array}$ & & -0.295 \\
\hline $\begin{array}{l}\text { Overall minimum tax for parent with foreign } \\
\text { ETR }<15 \% \text { with expensing }\end{array}$ & & -0.040 \\
\hline \multicolumn{3}{|l|}{ High-tax investment (statutory rate $=0.25$ ) } \\
\hline Current law & 0.242 & 0.130 \\
\hline Full inclusion & 0.300 & 0.300 \\
\hline Dividend exemption & 0.214 & 0.107 \\
\hline Japan minimum tax & & 0.214 \\
\hline Per-country minimum tax & & 0.121 \\
\hline Per-country minimum tax with expensing & & 0.121 \\
\hline $\begin{array}{l}\text { Overall minimum tax for parent with foreign } \\
\text { ETR }>15 \%\end{array}$ & & 0.107 \\
\hline $\begin{array}{l}\text { Overall minimum tax for parent with foreign } \\
\text { ETR }<15 \%\end{array}$ & & 0.150 \\
\hline $\begin{array}{l}\text { Overall minimum tax for parent with foreign } \\
\text { ETR }>15 \% \text { with expensing }\end{array}$ & & 0.107 \\
\hline $\begin{array}{l}\text { Overall minimum tax for parent with } \\
\text { foreign } \mathrm{ETR}<15 \% \text { with expensing }\end{array}$ & & 0.000 \\
\hline
\end{tabular}

Notes: Details are provided in the text and Appendix B, http://econweb.rutgers.edu/altshule/ Technical\%20appendices.htm). 
limited because it does not exploit valuable intangibles. The cost of shifting function is adjusted to reflect these limited opportunities.

In the simulations for current law, we assume, on the basis of the above analysis of the response to the repatriation tax holiday, that the burden of the repatriation tax on dividends from the low-tax subsidiary is 5 percent of subsidiary pre-tax income if the parent is not in excess credit. This includes both the tax on actual dividends and the implicit cost of avoiding repatriations. We assume the burden on repatriations from the high-tax country is 1 percent of subsidiary pre-tax income. The company has some expectation of being in excess credit but we weight this frequency at only 0.2 , lower than past experience, because of the new anti-splitter rules restricting the extent to which foreign tax credits can be magnified relative to the income being repatriated. If the company is in excess credit, its subsidiary will pay greater royalties because they will now be free from U.S. tax.

Because of the distinction between pre- and post-check-the-box tax planning, effective tax rates for each scenario are presented for two cases. The first is for the situation before check-the-box when stripping income to tax havens was restricted by the subpart $F$ rules. The second case is for the tax-planning environment after check-the-box. After the implementation of check-the-box, income in both the high-tax and low-tax country could be shifted to a tax haven without triggering a current inclusion in U.S. taxable income. Because organizing hybrid entities under check-the box seems relatively simple, we assume that half of both high-tax and low-tax income is shifted to the tax haven.

The simulations consider low-tax and high-tax investments separately. Each investment is considered in turn so it gets the benefit of any additional shifting opportunities it creates. The formulas and further details on the simulations are provided in Appendix B. ${ }^{18}$

\section{B. Simulation Results}

Row one in Table 1 shows that there is a substantial negative effective tax rate on investing in the low-tax country, that is, a large tax subsidy under our current law baseline (current law with a 30 percent statutory U.S. rate). This is true even in the absence of check-the-box in spite of the substantial cost of the dividend repatriation tax we have assumed. The large tax subsidy is attributable to the combination of the benefits of underpaying the royalty by the low-tax subsidiary and the exemption of the royalties that are paid if firms expect to be in excess credit. There is also a visible effect on the effective tax rate in the high-tax subsidiary because of the opportunity for shifting income to the low-tax subsidiary.

As shown in column two for current law, check-the-box has a large impact on effective tax rates. Effective tax rates on investment in both locations decline substantially. This is particularly apparent in the high-tax location because of the opportunity for shifting formerly highly taxed income to a tax haven. In addition, less income from the

${ }^{18}$ See Appendix B, http://econweb.rutgers.edu/altshule/Technical\%20appendices.htm. 
high-tax location is shifted to the low-tax subsidiary because of the new opportunity for shifting to a tax haven. The gap between the effective tax rates in the two locations gets much narrower. For non-tax reasons, the company may therefore decide to locate the high tech operation in the high-tax location.

Under full inclusion there is no repatriation burden as all income earned abroad bears a current U.S. tax. The second row shows the 30 percent effective tax rate that applies to new investment in both countries. There is no incentive to shift income but also no incentive to lower any foreign tax, unless the company is in an excess credit position.

The third row shows that the elimination of the repatriation tax under dividend exemption pushes the effective tax rate in the low-tax country even further into negative territory than under current law. Dropping the dividend repatriation tax outweighs the full taxation of royalties under dividend exemption. Because of the assumed quadratic cost of shifting function, and therefore a linear marginal cost of shifting function, the benefits of income shifting depend on the square of the tax differential. So the increase in the tax differential from 20 percentage points $(30 \%-10 \%)$ to 25 percentage points $(30 \%-5 \%)$ has a significant impact. With check-the-box, the effective tax rate is the equivalent of almost a 30 percent subsidy for investment in the low-tax location. This comparison of current law and dividend exemption differs from earlier estimates (Altshuler and Grubert, 2001) because the response to the 2005 repatriation tax holiday and the new anti-splitter legislation requires an adjustment to the burden of the repatriation tax and the frequency of excess credit positions.

The next row has the Japanese type dividend exemption system with a minimum tax of 15 percent in each location. Recall that there is an exception for active businesses so the low-tax and high-tax operations with real investment qualify. The tax haven does not qualify because it has no real operations. Neither the low-tax subsidiary nor the high-tax subsidiary would use the tax haven because of the cliff created by the Japanese type system. Any tax haven income would be taxed at the U.S. rate of 30 percent rather than 5 percent in the low-tax country or 25 percent in the high-tax country. Therefore this proposal just gets us back to dividend exemption without check-the-box, which is confirmed by the estimates.

The anti-base-erosion alternative in the Camp bill that is modeled on the Japanese system seems much tougher than just requiring an active business. It appears that it is necessary to serve mainly local customers to avoid the full inclusion. If this causes the low-tax subsidiary to fail the test, it creates the rather bizarre incentive to pay a tax greater than 15 percent to escape the cliff.

The next two rows in Table 1 show effective tax rates for the 15 percent per-country minimum tax. In contrast to the previous Japanese type dividend exemption with a minimum tax, there is no exception for an active business. There is also no cliff so any income that is taxed at a tax rate below 15 percent only pays the amount to the United States that would raise the total tax rate to 15 percent. Dividends after any minimum tax has been paid are exempt. The first version does not have expensing against the U.S minimum tax base in the location and the next row includes the expensing variation. 
The implications of this proposal are much different than those under the Japanese type variation of dividend exemption. Investment in the low-tax country gets no active business exception. Its income is always taxed at 15 percent whether it is shifted to the tax haven or not. On the other hand, the high-tax country continues to benefit from having its income shifted to a tax haven. In the tax haven it pays only 15 percent compared to 25 percent in its home location. In contrast to the cliff case that also means the United States receives the 15 percent tax on the tax haven income.

This version of the minimum tax has a substantial effect on the effective tax rates. Note that in the no expensing case the effective tax rate in the low-tax location rises to 5.6 percent, very close to the country's actual undistorted rate and much higher than the earlier version of the minimum tax with the active business exemption. It is not as high as 15 percent, the minimum tax rate, because the 15 percent differential from the U.S. rate and the 10 percent differential from the high tax rate still induce income shifting (from the U.S. to the low-tax operation and from the high-tax operation to the low-tax operation). Furthermore, the effective tax rate on investment in the high-tax country is substantially below the country's nominal rate because there is still a tax benefit from using check-the-box to locate income in the tax haven.

In the low-tax country, the expensing alternative that exempts the normal investment return results in a negative effective tax rate, but the effective tax subsidy is much smaller than under pure dividend exemption. Instead of bearing the 15 percent minimum tax, the normal return just pays the local 5 percent. In the high-tax country, the opportunity to expense investment has no effect because any income there is not subject to the minimum tax.

There may be some concern that allowing expensing against the minimum tax on foreign income, but not on domestic income, will result in "runaway plants". The simulations show that this fear is unwarranted. Even with expensing the minimum tax results in a much higher effective tax in the low-tax country than under current law.

The next rows show effective tax rates under the overall minimum tax. The rates will differ depending on whether the company's overall effective tax rate on foreign source income is above or below the 15 percent minimum tax threshold. We assume in our simulations that there are existing operations abroad that determine whether the company is above or below this threshold and that any new investment will not affect the company's status. Companies above the threshold owe no minimum tax and thus have the same incentives as under dividend exemption.

For companies below the threshold, additional income anywhere earned on an investment is taxed at the minimum tax rate of 15 percent. There is no longer an incentive to shift income to the tax haven or from the high-tax to the low-tax country. Companies will still have an incentive to shift income out of the United States, however. Table 1 shows that the effective tax rate for investment in the low-tax country is 6 percent, which is slightly higher than the effective tax rate under the per-country minimum tax since there is no shifting from the high-tax to the low-tax operation. The effective tax rate for the routine investment in the high-tax country is 15 percent, the minimum tax rate, since in our model there is no mechanism in the form of intangibles or debt for 
the company to shift income from the United States to the high-tax country. (But the overall minimum tax could induce the company to set up the high-tech investment in the high-tax country. The effective tax rate on this investment would be 6 percent, the same as for the high-tech investment in the low-tax country. Similarly, a routine investment in the low-tax country would face an effective tax rate of 15 percent.)

The overall minimum tax could be combined with expensing so as to tax only the excess returns earned abroad. The effective tax rate for the investment in the low-tax country for a company below the overall minimum tax threshold would be -4.0 percent. As with the alternative with no expensing, the effective tax rate is slightly above the per-country effective tax rate since there is no incentive to shift income from the high-tax to the low-tax operation. Companies above the threshold would face the same incentives as dividend exemption under the expensing option yielding an effective tax rate of 10.7 percent. They owe no minimum tax and have an incentive to use the haven as long as they remain above the threshold.

The routine investment in the high-tax country earns only a normal return, which would be exempt from U.S. tax under expensing. The normal foreign tax would be due on the pre-expensing base, which would increase the spillover of credits against the U.S. tax liability. These credits reduce the total tax liability of the investment. With full expensing, the effective tax rate would be zero in the high-tax country for firms below the threshold. Companies above the threshold would have the same incentives as under dividend exemption.

Finally, we can compare the repeal of check-the-box under current law with the introduction of a minimum tax while keeping check-the-box. As shown in column one for current law, tax planning before check-the-box still provided many opportunities for income shifting, as is evident from the significant negative effective tax rate in the low-tax country. The effective tax rates under the per-country minimum tax are much closer to the nominal low-tax country rate. The same is true for parents with effective tax rates on foreign income below 15 percent under the overall minimum tax. Furthermore, under both the per-country and overall minimum taxes, the high-tax country can still use the tax haven to lower its tax rates, and the United States will therefore collect the 15 percent on the tax haven income.

\section{Simulations of U.S. and Foreign Revenue}

Table 2 presents the U.S. and foreign revenue resulting from the investments in the scenarios. The pattern is in general what the effective tax rates in Table 2 would lead one to expect. In each case, an investment of $\$ 100$ is assumed with a normal return of $\$ 10 .{ }^{19}$ In all cases except full inclusion the investment in the low-tax country results in a revenue loss for the United States. The small amount received from actual repatriations

\footnotetext{
19 We are implicitly assuming that the capital fo: the investment would not have yielded any revenue if invested elsewhere. Estimates comparing these investments with an investment in the United States earning a normal return would have yielded similar results.
} 
Table 2

Tax Revenue on $\$ 100$ Investment in Low and High-Tax Countries

\begin{tabular}{|c|c|c|c|c|}
\hline & \multicolumn{2}{|c|}{ Before Check-the-Box } & \multicolumn{2}{|c|}{ After Check-the-Box } \\
\hline & $\begin{array}{l}\text { U.S. Tax } \\
\text { Revenue }\end{array}$ & $\begin{array}{l}\text { Foreign Tax } \\
\text { Revenue }\end{array}$ & $\begin{array}{l}\text { U.S. Tax } \\
\text { Revenue }\end{array}$ & $\begin{array}{l}\text { Foreign Tax } \\
\text { Revenue }\end{array}$ \\
\hline \multicolumn{5}{|l|}{ Low-tax investment (statutory rate $=0.05$ ) } \\
\hline Current law & -5.20 & 0.69 & -4.87 & 0.54 \\
\hline Full inclusion & 2.50 & 0.50 & 2.50 & 0.50 \\
\hline Dividend exemption & -6.00 & 0.79 & -6.60 & 0.62 \\
\hline Japan minimum tax & & & -6.00 & 0.79 \\
\hline Per-country minimum tax & & $\cdot$ & -1.33 & 1.01 \\
\hline $\begin{array}{l}\text { Per-country minimum tax with } \\
\text { expensing }\end{array}$ & & & -2.33 & 1.01 \\
\hline $\begin{array}{l}\text { Overall minimum tax for parent with } \\
\text { foreign } E T R>15 \%\end{array}$ & & & -6.60 & 0.62 \\
\hline $\begin{array}{l}\text { Overall minimum tax for parent with } \\
\text { foreign ETR }<15 \%\end{array}$ & & & -1.40 & 1.10 \\
\hline $\begin{array}{l}\text { Overall minimum tax for parent with } \\
\text { foreign ETR }>15 \% \text { with expensing }\end{array}$ & & & -6.60 & 0.62 \\
\hline $\begin{array}{l}\text { Overall minimum tax for parent with } \\
\text { foreign ETR }<15 \% \text { with expensing }\end{array}$ & & & -2.40 & 1.10 \\
\hline \multicolumn{5}{|l|}{ High-tax investment (statutory rate $=0.25$ ) } \\
\hline Current law & 0.16 & 1.90 & 0.15 & 1.10 \\
\hline Full inclusion & 0.50 & 2.50 & 0.50 & 2.50 \\
\hline Dividend exemption & 0.00 & 1.79 & 0.00 & 1.07 \\
\hline Japan minimum tax & & & 0.00 & 1.79 \\
\hline Per-country minimum tax & & & 0.82 & 1.16 \\
\hline $\begin{array}{l}\text { Per-country minimum tax with } \\
\text { expensing }\end{array}$ & & & 0.11 & 1.16 \\
\hline $\begin{array}{l}\text { Overall minimum tax for parent with } \\
\text { foreign ETR }>15 \%\end{array}$ & & & 0.00 & 1.07 \\
\hline $\begin{array}{l}\text { Overall minimum tax for parent with } \\
\text { foreign } \mathrm{ETR}<15 \%\end{array}$ & & & 0.00 & 2.50 \\
\hline $\begin{array}{l}\text { Overall minimum tax for parent with } \\
\text { foreign ETR }>15 \% \text { with expensing }\end{array}$ & & & 0.00 & 1.07 \\
\hline $\begin{array}{l}\text { Overall minimum tax for parent with } \\
\text { foreign ETR }<15 \% \text { with expensing }\end{array}$ & & & 0.00 & 2.50 \\
\hline
\end{tabular}

Notes: Details are provided in the text. 
under current law is far outweighed by the loss from the income shifted out. The loss to the United States widens after the introduction of check-the-box and even further under pure dividend exemption. But the loss is reduced significantly under the per-country minimum tax both with and without expensing (and under the overall minimum tax when the company is below the threshold). Not surprisingly, foreign governments always gain less than the United States loses. The foreign gain is somewhat greater under both forms of the minimum tax than under the dividend exemption option because it is less advantageous to shift income from the high-tax country to the low-tax country.

As noted in the discussion of the effective tax rates, the Japanese version of dividend exemption returns the system to dividend exemption before check-the-box. But the differing revenue impact of the Japanese version and the per-country minimum tax from investment in the high-tax country is notable. Because of the cliff in the Japanese type of scheme, the high-tax subsidiary would not use check-the box to shift income to the tax haven because it would be taxed at 30 percent rather than 25 percent at home. Under the per-country minimum tax, the subsidiary still gets a tax saving from using the tax haven, a tax rate of 15 percent rather than 25 percent. That means that the United States gets the 15 percent rather than having the income all taxed in the high-tax foreign country. The overall minimum tax generates no tax revenue for the United States for investment in high-tax countries regardless of whether the company is above or below the threshold.

\section{Expense Allocations Under the Minimum Tax}

Any dividend exemption system raises the issue of parent overhead deductions like interest and whether there should be allocations to exempt income. If there is a denial of parent interest deductions in the case of the minimum tax, the allocations are presumably based on worldwide fungibility. Furthermore, since the income below the 15 percent threshold is subject to U.S. tax, any interest allocated abroad should receive a deduction at the rate at which the income would be taxed by the United States. For example, in a country with a 5 percent tax rate, the U.S. tax would be 10 percent of income and the allocated interest should be deductible at that rate. A company could of course avail itself of self-help by shifting debt abroad and getting a combined deduction of at least 15 percent.

The question is how much impact this allocation would have in low-tax countries compared to the impact of the minimum tax and its effect on income shifting. Consider a hypothetical case. Assume that 25 percent of the investment in a low-tax country is in the form of parent debt that gets allocated. The company engages in self-help and obtains a deduction at 15 percent. The tax differential between the deduction abroad and the deduction at home is therefore 15 percent. If the interest rate is equal to the normal pre-tax rate of return on the entire investment, the allocation raises the effective tax rate on the investment by 3.75 percentage points. Even though this is likely to be an overestimate because of our expansive assumptions, it is modest compared to the impact of the minimum tax on the effective tax rate in low-tax countries revealed in 
the simulations in Table 1. For example, the country-by-country minimum tax raises the effective tax rate on a high tech investment in a country with a 5 percent tax rate by more than 25 percentage points. The reason for the discrepancy is that the allocated debt is based only on the operation's capital while the minimum tax applies to the entire base of income, including the large amount shifted from the parent. Unlike interest allocation, the minimum tax reduces the marginal incentive to shift income.

\section{REVENUE}

\section{A. What Does Revenue Depend on?}

The simulations illustrate some factors that affect revenue. More generally the impact of the proposals on revenue will depend on the following elements:

1. The direct tax on each source of foreign income.

2. The extent of cross-crediting. This form of tax planning will still occur under full inclusion so that, for example, royalties will be shielded if the company is in an excess credit position. High-tax income in a location can also offset low-tax income elsewhere. The frequency of excess credits may, however, decline under full inclusion because of the inclusion of low-tax income in the tax base. There is no cross-crediting under the dividend exemption or per-country minimum tax proposals. There will be some cross-crediting of equity income under the overall minimum tax (but not to royalties).

3. Parent overhead expense allocations. We assume they continue under full inclusion but not the other proposals.

4. The extent to which foreign losses can be deducted from domestic taxable income. Under full inclusion we assume foreign losses can come home. Losses do not come home under the other proposals. However, as described above, subsidiary losses do enter into the computation of its effective tax rate for the purpose of the minimum tax.

5. Behavioral responses. Each of the options will induce large responses, but of different types and magnitude. Under full inclusion the company has no incentive to lower foreign taxes as long as it does not have excess credits. But it also gets no benefit from shifting income out of the United States so more income would be taxed in the United States. On the other hand, under dividend exemption companies have the incentive to reduce any foreign tax because they have no value as credits. But the elimination of the repatriation tax under dividend exemption will increase income shifting from the United States because low-tax foreign income is now worth more. In addition, companies will tend to switch from taxable royalties to exempt equity income to the extent this is possible. 
The per-country minimum tax falls somewhere between these two extremes in terms of behavioral responses. Companies have no incentive to lower foreign taxes in a location below a 15 percent rate, but they will attempt to lower taxes above that threshold. Hybrid entities will still be used to shift high-tax income to tax havens where the U.S. per-country minimum tax rate of 15 percent applies. Because the minimum tax exempts dividends, there will be a tendency to switch from royalties to equity income, but the benefit is smaller than under dividend exemption because the tax differential is 15 percent rather than 30 percent. And the tendency to increase income shifting because of the elimination of the repatriation tax appears to be more than offset by the minimum tax. Indeed, the effective tax rate simulations suggest that shifting to low-tax locations will be much smaller than under current law. In terms of investment location incentives, the effect of the per-country minimum tax is smaller than under full inclusion. Behavioral responses to the per-country minimum tax that reduce U.S. tax revenue therefore seem muted compared to either dividend exemption or full inclusion.

Behavioral responses for the overall minimum tax depend on whether the company is above or below the minimum tax threshold. Companies above the threshold face the same incentives as are present under dividend exemption. Companies below the threshold have similar incentives to those present under the per-country minimum tax.

\section{B. Revenue from Foreign Source Income under Current Law}

Treasury tax returns indicate that in $2006, \$ 32.0$ billion of revenue was collected on all of corporate foreign source income. This amounted to less than 4 percent of all foreign income including deferred profits but before allocated parent expenses. But the amount raised from dividends represents only a very small portion of this revenue. Indeed, if dividends are removed from taxable foreign income total US tax revenue increases by about one billion. The dividends taxable on the margin after credits are more than offset by the credits originating with dividends that currently spill over to other income. The residual tax is obtained from royalties, passive income, export sales source income and branch income.

\section{Some Static Revenue Comparisons of Reform Alternatives}

We do not present full revenue estimates because they require precise knowledge of the various possible behavioral responses. But we can discuss the static no-behavioral change estimates in relative terms and speculate on the behavioral responses. ${ }^{20}$ The tabulations discussed below are from the 2006 Treasury corporate tax return files and assume a 30 percent tax rate for the United States.

${ }^{20}$ We are very grateful to Ralph Rector for these tabulations. For the minimum tax the tabulations required the imputation of tax to a CFC's disregarded entities under check-the-box. 
Because of the decline in average effective foreign tax rates that companies pay and the large amount of deferred income in low-tax jurisdictions, the static revenue gain from repealing deferral is very large. The 15 percent per-country minimum tax without expensing gains almost exactly half of the static full inclusion amount. About 55 percent of total E\&P (net of dividends received from related parties) is in entities subject to the per-country minimum tax, an indication that a large portion of $\mathrm{MNC}$ income bears a very low rate of tax. There is very little reduction in static revenue when expensing is added to the per-country minimum tax proposal. It turns out that little real investment takes place in the locations affected by the minimum tax.

Finally, on a static basis pure dividend exemption is virtually revenue neutral. This is, however, without adjusting for the anti-splitters legislation, which would reduce excess foreign tax credits that shield royalties under current law. That would increase the cost of converting to dividend exemption under which royalties are fully taxed.

\section{How Much Would Companies Be Willing to Pay for Dividend Exemption?}

As we have seen, the evidence from the 2005 repatriation tax holiday suggests that the burden of the dividend repatriation tax is substantial, above 5 percent for the highly profitable, $R \& D$ intensive companies that account for much of foreign deferred income. This burden will increase as deferred income continues to accumulate. Bureau of Economic Analysis data on retained earnings indicate that they are now much higher than their pre-2005 peak.

In determining what minimum tax rate companies would be willing to accept, it is important to put the tax holiday rate of 5.25 percent and the 15 percent per-country minimum tax on a comparable footing. Unlike the repatriation holiday with a proportionately scaled down (by 15 percent of foreign tax actually paid) credit, a full credit for the foreign tax would be given against the U.S. tax liability in a country under the minimum tax. In a country with a 5 percent effective tax rate, for example, the burden of the 15 percent minimum tax would be 10 percent. The burden of the 5.25 percent repatriation holiday rate would be 4.5 percent after scaled down credits $(5.25-0.15 \times 5)$. If the local tax rate is higher, say 10 percent, the 3.75 tax under the holiday $(5.25-0.15 \times 10)$ is not far from the 5 percent U.S. tax under the minimum tax. Of course, the minimum tax would not apply for effective foreign tax rates 15 percent or above, unlike the tax under the holiday.

On the basis of the tax holiday evidence, we assumed in the simulations that the marginal cost of additional deferrals in a low-tax country was 5.0 percentage points. If we assume that the average cost of the repatriation tax is 2.0 percentage points for all of foreign earnings, the benefit to the companies of exempting dividends is about equal to the static revenue gain from a 10 percent per-country minimum tax or a 15 percent overall minimum tax. By the same token, the companies' gain from dividend exemption would offset 50 percent or more of their added U.S. tax liabilities from a 15 percentage point minimum tax. 


\section{E. Will Host Countries Soak Up the Minimum Tax?}

Tax haven countries might be tempted to raise their tax on U.S. operations to soak up the minimum tax because they would not risk losing U.S. investment. This would reduce the revenue the Treasury obtains but not the impact of the minimum tax on income shifting or the location of investment. It is difficult to make any firm predictions, but the following considerations suggest that it is not likely to be an important phenomenon:

1. In many low-tax countries, direct investment by U.S. based companies does not account for a major share of Foreign Direct Investment (FDI). For example, Organisation for Economic Co-operation and Development (OECD) statistics indicate that in 2007, U.S. direct investment in Ireland only accounted for 14 percent of total FDI in Ireland. ${ }^{21}$ Also, the Allen and Morse (2011) analysis of IPOs on U.S. markets shows that many foreign companies, particularly from China, use tax havens such as Bermuda as a conduit. The tax havens would have to discriminate against U.S. companies to soak up the minimum tax.

2. The "soak up" rules in Section 901 would be applied to credits under the minimum tax. They deny a credit under current law to cases when a foreign tax depends on the availability of a credit in the home country. Rules under current law also restrict credits in cases where the tax on U.S. companies is not a generally applicable tax.

3. Pure tax havens like Bermuda are very unlikely to increase their tax on U.S. companies. They do not now have an income tax on corporations and would have to introduce one, threatening their tax haven status.

4. If soaking up the minimum tax is a significant possibility, the credit for foreign taxes could be limited, similar to the 95 percent exemption of dividends in many territorial systems.

\section{THE OVERALL VERSUS THE PER-COUNTRY MINIMUM TAX}

A minimum tax at the level of all active foreign income rather than on a countryby-country basis may be simpler than the per-country option. For example, as noted above, it would not be necessary to allocate the assets in a foreign acquisition to particular locations under the overall minimum tax. It might be successful in targeting the companies that can best exploit a low foreign tax rate. The incentives that a company faces may be usefully summed up by its overall foreign tax rate without having to look at individual country.

We compare a 15 percent minimum tax on all foreign income with a per-country minimum tax at 10 percent to indicate whether the overall minimum is a serious option.

\footnotetext{
${ }^{21}$ We are grateful to Laura Power for providing us with these statistics.
} 
The 2006 Treasury data indicate that the static revenue gains from the two alternatives are very similar. The comparison depends in part on how much foreign income is earned by companies with effective tax rates on foreign income above 15 percentage points. The companies above the threshold would enjoy the equivalent of dividend exemption with no U.S. tax liability, even on low-tax income, apart from the tax on royalties. One question therefore is how much current low-tax income would be exempt. The companies could also increase tax haven income without confronting the problem of a U.S. repatriation tax. The easiest way for these companies to lower their average foreign tax rate would be to expand their use of check-the-box rather than investing in real activities in low-tax countries.

In contrast, for companies below the threshold, any new investment would have an effective tax rate of exactly 15 percent. Any additional income is taxed at 15 percent. As indicated in the simulations above, this holds true even for investments in high-tax locations because any foreign tax in excess of 15 percent can be used to reduce the U.S. tax.

For a systematic comparison of the 10 percent per-country minimum and the 15 percent overall minimum, we use the 2006 Treasury files to construct the distributions of effective foreign tax rates at the CFC level under each proposal and, in particular, the effective tax rates relevant for new investments. As illustrated in the simulations for the post check-the-box cases, the effective tax rate on real investment in a country depends both on the tax on the income where the investment is located and the tax in the haven to which income is diverted with the use of check-the-box. That is the reason for looking at effective tax rates at the consolidated CFC level. The question is whether the overall minimum tax leaves a large amount of low-tax income unaffected.

In constructing the distribution for the effective foreign tax rate on new investment under the overall minimum tax, we assume that the increase in investment under current law is proportional to the CFC's current E\&P. New investment is likely to be where the old capital already is. Each minimum tax proposal may move that investment to another effective tax category. The distributions for the alternatives are therefore in the nature of static estimates before behavioral responses to the new regimes.

As indicated above, all new investment by CFCs owned by MNCs below the 15 percent threshold are given a tax rate on new investment of 15 percent under the overall minimum tax. The CFCs of those MNCs above 15 percent are just given their actual effective tax rates because they are not affected by the U.S. tax. ${ }^{22}$

Table 3 presents the distributions. ${ }^{23}$ The first column presents the share of total E\&P before tax in each effective tax rate category under current law. It indicates that 46

${ }^{22}$ The distributions therefore differ from the assumptions in the effective tax rate simulations above in two ways. No attempt is made to add the burden of the U.S. dividend repatriation tax under current law. In addition the effective tax rates do not take the tax saving from income shifting into consideration.

${ }^{23}$ The table includes data for CFCs that reported both income and foreign tax on IRS Form 5471. The table only includes CFCs where the sum of income for all CFCs controlled by a common parent was positive. Also, the $\mathrm{CFC}$ itself must have positive income to be included in the table. (The 2006 Treasury files show that about 36 percent of CFCs did not have positive income.) Finally, CFCs were not included if their foreign tax was 


\begin{tabular}{|c|c|c|c|}
\hline \multicolumn{4}{|c|}{$\begin{array}{l}\text { Table } 3 \\
\text { Distributions of Effective Tax Rates on New Investment } \\
\text { (CFC Level) }\end{array}$} \\
\hline & \multicolumn{3}{|c|}{ Percentage of Total Income } \\
\hline$:$ & Current law & $\begin{array}{l}\text { Overall Minimum } \\
\text { Tax at } 15 \text { Percent }\end{array}$ & $\begin{array}{l}\text { Per-Country } \\
\text { Minimum Tax } \\
\text { at } 10 \text { Percent }\end{array}$ \\
\hline \multicolumn{4}{|c|}{ Effective tax rate category } \\
\hline $\begin{array}{l}0 \text { to }<5 \text { percent } \\
5 \text { to }<10 \text { percent } \\
10 \text { percent } \\
>10 \text { to }<15 \text { percent } \\
15 \text { percent } \\
>15 \text { to }<20 \text { percent } \\
20 \text { to }<25 \text { percent } \\
25 \text { to }<30 \text { percent } \\
\geq 30 \text { percent }\end{array}$ & $\begin{array}{r}36.8 \\
9.1 \\
0.4 \\
7.4 \\
0.3 \\
8.6 \\
6.9 \\
6.5 \\
24.0\end{array}$ & $\begin{array}{r}12.6 \\
3.9 \\
0.3 \\
5.3 \\
37.1 \\
7.5 \\
6.1 \\
5.7 \\
21.5\end{array}$ & $\begin{array}{r}42.3 \\
11.0 \\
0.3 \\
8.1 \\
7.4 \\
6.8 \\
24.2\end{array}$ \\
\hline \multicolumn{4}{|c|}{$\begin{array}{l}\text { Notes: Calculations are based on Form } 547 \mathrm{I} \text { earnings and profits (E\&P) data for } 2006 \text { and assume } \\
\text { additional investment income proportional to the CFC's } 2006 \text { E\&P. The sample parents with positive } \\
\text { total E\&P only. The text provides details. }\end{array}$} \\
\hline
\end{tabular}

percent of $2006 \mathrm{E} \& \mathrm{P}$ is in CFCs with effective foreign tax rates below 10 percent. The next column presents the effective foreign tax rate on new investment under the 15 percent overall minimum. There is a very substantial reduction, of about two-thirds, in investment with effective tax rates below 10 percent. That leaves 16.5 percent of total income in CFCs with effective tax rates below 10 percent that are unaffected by the overall minimum, compared to 46 percent of total income under current law. The unaffected low-tax CFCs are owned by parents above the overall threshold.

Looking further down column 2 for the overall minimum tax, 37 percent of total investment would have an effective tax rate exactly at 15 percent. In addition, the CFCs paying high foreign taxes under current law are not much affected by the minimum tax. The amount of E\&P in the high tax rate categories is close to the E\&P in the categories under current law. Very few of them now have an effective tax rate on new investment at 15 percent because most are owned by parents above the threshold.

negative or if the sum of foreign tax across all of a parent's CFCs was negative. Adjustments were made to $\mathrm{CFC}$ income to account for ownership percentage and for income that was transferred between entities that were controlled by the same parent. In addition, total CFC income and tax was allocated between the CFC and connected foreign disregarded entities (if they were present). Foreign tax for disregarded entities was based on country-level imputations. 
Column 3, for the 10 percent per-country minimum tax, shows that, as expected, a large amount of investment will be taxed exactly at 10 percent and no investment will have a lower tax burden. ${ }^{24}$ It is possible that the per-country minimum raises effective tax rates even for CFCs with relatively high effective tax rates because some of the entities it owns are in a tax haven and therefore subject to the minimum tax. But the high-tax categories in column 3 indicate that this effect is relatively modest when they are compared with column 1 (current law) ${ }^{25}$ Columns 2 and 3 both suggest that a parent having both high-tax and low-tax CFCs is relatively uncommon.

The overall minimum tax appears to be successful in targeting the companies that have the greatest opportunities for shifting income, although of course not as effectively as the per-country minimum. The reason is suggested by regressions (not shown) based on 2004 Treasury tax return data which indicate that MNCs that are R\&D intensive and earn high worldwide profit margins have significantly lower overall effective foreign tax rates. For example, a company with both a worldwide profit margin and the ratio of R\&D to sales one standard deviation above their respective means has a foreign effective tax rate about 4 percentage points below the mean.

The distributions shown in Table 3 are based on corporate returns for 2006 without any adjustments for potential behavioral responses by the companies or governments. They would differ between the two alternative types of minimum taxes. For example, under an overall minimum, tax havens would be much less likely to raise their tax on U.S. companies to soak up the minimum tax. They would not be in a position to know each company's overall worldwide position. Indeed, U.S. companies in the same jurisdiction may be on different sides of the overall tax threshold.

The companies would also react somewhat differently under the two alternatives. The per-country minimum tax decreases the benefits of a low-tax location so companies would shift more investment to relatively high-tax countries including the United States. They would continue to use hybrid entities to shift income from countries with tax rates above the minimum tax. Under the overall minimum tax, the response depends on whether the company finds itself above or below the minimum tax threshold. Below the threshold, all new investment has the same effective tax rate so there would be a significant shift to higher tax foreign countries both compared to current law and also compared to the per-country minimum. Hybrid entities would provide no benefit and some may be unwound. If the $\mathrm{MNC}$ is above the overall threshold, it would increase its low-tax investments because of exemption. They would become

24 The minimum tax calculations for column 3 were made for each country associated with a CFC and its disregarded entities. The calculations were based on a consolidation of income by country for the entities associated with the CFC but not across CFCs. Permitting consolidation of country income across CFCs would reduce the impact of the minimum tax because the aggregation could bring in entities with effective tax rates above 10 percent or with losses.

${ }^{25}$ If a CFC has a loss in an entity in one country and a gain another country, the minimum tax on the latter could make the CFCs effective tax rate substantially above 10 percent. But we exclude these possibilities in Table 3. 
more attractive because of the disappearance of the repatriation tax on dividends. Furthermore, using a hybrid to strip income from any country with a positive tax offers a benefit.

Summing up, the overall minimum tax seems a serious alternative to the per-country minimum tax. It is not as successful at targeting tax haven investments but it is much simpler. It would also provoke fewer attempts by foreign jurisdictions to soak up the U.S. tax.

\section{$X$. INCENTIVES TO EXPATRIATE}

Because proposals like the minimum tax will increase MNCs' tax liabilities relative to current law, the possibility that this will cause some of them to expatriate is a concern. ${ }^{26}$ The issue of expatriation has come back into focus by the recent decision by Aon, a major insurance broker, to move its tax residence to the United Kingdom. The company already has business operations in the United Kingdom, so. it believed the transaction would not be restricted by the anti-inversion provisions in Section 7874. In the prospectus for the reorganization, the company stated that it expected its worldwide tax rate to go down from 30 percent to 26 percent, which seems much more than could be explained by any tax on its dividend repatriations. It could be that it has trouble qualifying for exceptions to subpart $F$ treatment of insurance income. (It apparently expected a loosening of the UK CFC rules and had already been granted a two-year exemption from the CFC rules.) We should note that the plan is for a stock transaction, so it is apparently not governed by Section 367 on the transfers of intangible property from the United States. Any existing intangible assets will still reside with the U.S. entity. But shareholders in Aon will have to recognize a capital gain on the transaction.

It is useful to first consider why expatriation is harmful to the United States. Aon stated that it would move 20 key executives to London, so in this case the shift in headquarter services does not seem to be quantitatively very significant. It is similar to Halliburton's earlier (in 2007) shift of its headquarters to Dubai from Houston without changing its tax residence.

We might ask what makes an American company intrinsically an American company. It is presumably because that is where the source of excess returns originate, particularly the intangible assets or "know how" developed in the United States. Under an income tax the contribution of know how should be taxed where it is developed like any other input. Getting the value of these intangibles outside the U.S. tax net may be a reason

\footnotetext{
${ }^{26}$ Shaviro (2011) discusses the electivity of corporate residence under current law and its implications for tax policy. Allen and Morse (2013) examine firms that conducted initial public offerings in the United States between 1997-2010 to determine the extent to which firms incorporate in tax havens. Their careful analysis suggests that few U.S. start-ups incorporated in tax havens over the period examined.
} 
for expatriation, although companies now do not seem to have any trouble migrating their intangibles.

Another source of observed excess returns is the initial risk taking when the company was established. There are examples in recent IPOs of companies in which the know how was developed in the United States but the venture capital financing came from abroad. That offers some justification for a foreign tax residence.

Companies may choose to expatriate because it puts them in a better position to strip income out of the United States using intercompany debt. Presumably that is due to the weaknesses in Section $163(\mathrm{j})$, the object of which is to restrict interest stripping from the United States. ${ }^{27}$ Apart from avoiding the tax on dividend repatriations, a company may also wish to escape the strictures of the subpart $F$ rules although these have been greatly weakened by the check-the-box provisions.

Turning now to the alternative proposals, the large increase in U.S. tax burdens under full inclusion will increase incentives for expatriation. Dividend exemption will reduce them compared to current law. The minimum tax with expensing will tend to eliminate any incentive attributable to differences in the tax on the normal return to capital. Industries like oil drilling are highly capital intensive. On the other hand, the excess returns that are largely attributable to intangible assets would be taxed more heavily under the minimum tax. However, companies may be reluctant to go through the valuation problems involved in expatriating the intangibles. In any case, it is difficult to predict the net effect of the minimum tax on expatriation. The proposal could also be linked with a change in section 163 (j) to limit the opportunities for earnings stripping provided by expatriation.

\section{COMPLEXITY UNDER THE ALTERNATIVE PROPOSALS}

Many factors affect the level of complexity under the various proposals.

1. Credit planning. Under the current system and full inclusion, that is, any worldwide system, foreign tax credits have to be calculated. Magnifying credits is an important planning strategy, although it will be somewhat restricted by the new anti-splitter rules. Credit calculations for active income disappear under the minimum tax and dividend exemption options. Foreign tax credits would still need to be calculated for passive income but that is a much smaller pool of income.

2. Expense allocations to foreign income. This is another important source of complexity in current law. ${ }^{28}$ We have assumed that allocations are not made under dividend exemption or any of the minimum tax options. (The issue is discussed above in Section VII.)

${ }^{27}$ Altshuler and Grubert (2010) suggested that a company's worldwide debt be allocated to various locations based on assets. This would apply to both U.S. and foreign-based MNCs, similar to one of the options in Section 882-5, which applies to the interest expense of foreign branches in the United States.

${ }^{28}$ Graetz and Oosterhuis (2001) provide an excellent discussion of interest allocation rules and the complexity imposing these rules creates. 
3. The determination of what is an active business under the active business exception in the Japanese-type version of dividend exemption. Determining what is an active finance exception to the current inclusion of financial income in U.S. taxable income has required elaborate rules. Interpreting the Japanese rules or the version in the Camp proposal is very difficult. It is not clear whether anything that would pass as active income under the current subpart $F$ rule would fail under this approach. Furthermore, it is difficult to design a conceptually coherent rule based on the destination of subsidiary sales, and the provision discriminates against small countries. Companies may choose a location as a base for worldwide sales for legitimate non-tax reasons. Subjecting them to a U.S. tax may leave them at a competitive disadvantage.

Expensing in the minimum tax is in part a substitute for an active business test. If the company is making real investments in a location, its current U.S. tax liability is reduced and its normal return is exempt.

4. The determination of E\&P by country and the computation of the average effective tax rate for the purposes of the per-country minimum tax is a major complication in the proposal (and is not necessary under the overall minimum tax alternative). As indicated above, we suggest that five years of tax, including the current year, and five years of pretax income be combined to compute the effective tax rate.

5. The allowance for foreign acquisitions under the per-country minimum tax with expensing. A large acquisition could create problems because the acquisition price might have to be divided among many locations. This should be based on the target's income in each of the locations. It is a problem that could be avoided under the overall minimum tax.

6. Potential subpart F simplification. Full inclusion would certainly make much of subpart F unnecessary. Subpart F rules would only be necessary to retain the active-passive income distinction for tax crediting purposes. Dividend exemption would render obsolete the Section 956 dividend provision requiring the current inclusion of CFC loans or investments in the parent. The current de minimis threshold for currently includable "Foreign Base Company Income," which includes passive income, is the lesser of $\$ 1$ million or 5 percent of the CFC's gross income. Because any foreign income would bear a tax of at least 15 percent under the minimum tax, that might justify raising the threshold.

7. The treatment of branch income. The dividend exemption plans would require new rules for branch income if it is also covered by the exemption. Instead of being inside the U.S. tax base under current law, branches would now be outside the U.S tax base. But this would simply require branches to be taxed like CFCs. They would, for example, be required to pay an explicit royalty for the use of any U.S. developed intangibles. 
8. Hybrid instruments. The dividend exemption schemes would also necessitate rules restricting the use of hybrid instruments that convert payments deductible in one country into exempt equity in the other, including in the United States after dividends are exempt. This is particularly important under the per-country option to ensure that wherever the foreign income is, it bears a (U.S. plus foreign) tax of at least 15 percent.

\section{SUPPLY CHAINS AND COMPETITIVENESS UNDER THE MINIMUM TAX?}

It is possible that one stage in a company's supply chain might be subject to the minimum tax while the overall tax rate on all the investments for the integrated product is high. But that is not an incorrect result. The location of the low-tax stage might have been chosen for tax reasons, including using it as a destination for income shifted from the other stages.

The U.S. company may have less after tax income than its foreign competitors because of the tax on the excess return. Would that put it at a competitive disadvantage? The concern seems to be that foreign MNCs will eventually have a lower cost of capital because they will have more retained earnings, a preferred source of financing. But this seems not to be a very significant possibility because the U.S. companies subject to the minimum tax tend to be very profitable with ample sources of finance. The elimination of the repatriation tax would also permit U.S. companies to make better use of their retained earnings. Moreover, the minimum tax proposal can be expected to be part of a revenue neutral tax reform that would strengthen the U.S. corporate sector.

\section{OTHER FIXES TO THE SYSTEM?}

\section{A. Is Formula Apportionment the Answer to Income Shifting?}

Formula apportionment is frequently argued to be the solution to income shifting because under this system intercompany transactions play no role in the division of income between jurisdictions (Avi-Yonah and Clausing, 2007.) In 2011, the European Commission proposed a Common Consolidated Corporate Tax Base, a version of formula apportionment, for the members of the European Union. As indicated in Altshuler and Grubert (2010), Formula Apportionment (FA) suffers from many conceptual and practical problems and appears to have no advantage over the current, admittedly flawed, Separate Accounting (SA) system.

Most discussions of FA fail to specify the goals of a transfer pricing or income allocation regime within an integrated tax system. In terms of efficiency; it is to preserve neutrality in the choice between related and unrelated party transactions. Both FA and SA distort these choices but in different ways.

The basic problem with FA is the asymmetry between the items in the formula and the sources of income. The principal sources of income shifting are intangible assets 
that create large excess returns and the location of worldwide company debt. But these never get into the formula. Companies can therefore exploit this asymmetry to locate more income in low-tax locations.

Under SA, an MNC with valuable intellectual property has an incentive to locate the high tech stage part of the production process in a low-tax location to justify large profits there. FA also distorts the company's decision-making in order to locate more of the excess return in the tax haven but along different margins. If the formula is origin based, using apportionment factors such as capital and payrolls, the company can shift any stage of production to the low-tax country, even a very routine stage, because it is equally successful in attracting the excess return. Furthermore, in the high-tax country, the company has an incentive to outsource all routine production while in the low-tax country it has the incentive to bring all suppliers under the company umbrella to get their labor and capital into the formula. Simulations in Altshuler and Grubert (2010) show that FA using a capital-based formula has no advantages over the current system in terms of distorting decision making even though it is assumed that a substantial amount of resources are now wasted in tax planning under SA.

Labor and payrolls are particularly convenient for manipulating the formula to shift excess returns. Since wages are deductible from the pool of income to be apportioned, an additional worker hired in a tax haven whose wage just equals their marginal product contributes a bonus to the company. The wages get into the formula and attract more of the excess return. The company has an incentive to hire relatively unproductive workers in the low-tax country.

Avi-Yonah and Clausing (2007) recommend exclusively sales-based apportionment on the grounds that the destination of sales is least susceptible to manipulation. A single sales factor is used in many formulas for corporate tax apportionment at the state level in the United States. But these formulas also provide many opportunities for restructuring activities to get more income into low-tax locations. A company can sell routine, labor-intensive products in a low-tax location. The company may also sell its products to an unrelated distributor in the tax haven. The final sales may be very difficult to trace, particularly if the product is a component incorporated into a final good. Another response would be for the company to do its own marketing and selling in low-tax countries while using unrelated sellers in high-tax countries. The wholesale prices would get in the formula for high-tax country sales and retail prices for low-tax country sales.

Some observers see sales-based FA as an intermediate step to a destination basis consumption tax like a VAT. We cannot judge the likelihood of this happening, but as outlined in Altshuler and Grubert (2010), a sales-based formula is very far from a destination basis consumption tax. It is not a consumption tax because investment goods are taxed like any other good and there is no deduction by the investing company. Furthermore, it applies only to corporate profits, not all of value added, which introduces trade distortions into an income tax. 
One advantage of a VAT or other destination principle consumption taxes is that the rebate on exports per dollar is the same as the VAT imposed on imports. Also, in a uniform VAT, all sectors are subject to the same tax-per-dollar of sales. As a result, there are no trade distortions, or distortions in the choice to invest abroad rather than at home. But the sales-based formula is applied to a corporate income tax in which companies have greatly varying levels of taxable profits relative to sales. Differences in capital intensity could be one reason. There would therefore be a large variety of rebates on exports and taxes on imports, with possibly large trade distortions.

Consider first the case of a unilateral FA system adopted by the United States. U.S. exporters may have very high profit margins on sales while foreign companies exporting to the United States may produce routine, labor-intensive goods with very low profit margins. In that case, the formula would constitute a significant export subsidy because the tax applies only to the profit portion of value added, unlike a true consumption tax. Taxing only one part of value added at the location of consumption can distort both production and consumption decisions. Furthermore there is the problem of a pure foreign exporter with no business in the United States and therefore out of the U.S. tax net.

If the sales-based formula were adopted by all countries and there is no nexus problem, there would be no trade distortion only in the rare cases where the sum of rebates on exports and taxes on imports always happen to be offsetting. This would be true, for example, if all countries had the same tax rates or all goods and services everywhere had the same profit margin.

\section{B. Willing Consumers as the Source of All Value?}

Apart from sales-based apportionment, there is the related view that corporate profits should be taxed at the locus of ultimate consumption. Willing consumers are what create value, it is claimed. The contribution of intangible assets like patents would therefore be taxed where the final good or service is consumed, not where the patent is developed or financed. In addition to the trade distorting effects of a sales-based formula and the absence of any conceptual reason for ignoring the creators of a good, this view confronts the problem of intermediate goods like components, machines, and software. Unlike a sales-based formula, where the first third-party sale is presumably what is relevant, under the "willing consumer" theory it is the final sale to a consumer that counts. The difficulty of identifying the location of the ultimate consumer is particularly acute in the case of business software and capital equipment. They can contribute to the production of a variety of goods and services over a long period of time. This problem does not arise under a true consumption tax like a destination basis VAT because of the invoice-credit mechanism.

Taxing corporate profits at the point of ultimate consumption presumably applies to sales in which the exporter has no economic presence in the consumer's location. A tax 
on a pure import is usually referred to as a tariff with its potential for distorting trade. To be sure, there are some extreme cases in which a tariff or its equivalent is justified to offset the effect of a corporate tax on the location of economic activity. As suggested in Grubert (2005), if an activity is both very mobile and capital intensive, it can move to a tax haven and export its goods or services to high-tax countries even if the tax haven is not the most efficient location. A tariff can offset this unproductive arrangement. In fact, this type of phenomenon is recognized in the tax code in the form of the excise tax of foreign insurance in section 4371. But this is very far from the "willing consumer providing value" argument.

Neither "taxing income where the goods are consumed" nor a sales-based formula is consistent with what is actually taxed in a true consumption tax. In a consumption tax, the excess return earned on the basis of a valuable patent is taxed when the owners of the patent consume the proceeds in their country of residence. The final consumers of the goods produced with the patent are just taxed on the earnings they spend in their country of residence, the same tax they would pay if they spent their income on another good.

One common justification for taxing income where the good is consumed, not where it is produced, is that the country of final consumption protects the intellectual property embodied in the good. The implication appears to be that the United States should tax imports under an income tax because the U.S. police prevent them from being stolen. The corporate tax is not generally characterized as a benefit tax. (If it were, the foreign tax would not be creditable in the current system.) If the host country protects companies' intellectual property, a user charge for the registration and protection of the patents and trademarks is better directed at the companies that actually benefit from the service.

In summary, the taxation of business income based on the location of ultimate consumption presents both conceptual and practical difficulties. It is not a path to a destination basis consumption tax or a solution to base erosion.

\section{Mandatory R\&D Cost-Sharing Agreements}

One method that has been discussed for recapturing parent contributions to excess returns is by mandating cost sharing agreements for $\mathrm{R} \& \mathrm{D}$. But that is inadequate. What are observed are the winners in the innovation race whose $R \& D$ expense. is a small percentage of their worldwide income. For example, Apple Corporation's 10K report for 2012 indicates that its R\&D expense is about 7.5 percent of its worldwide after tax income. Losing the domestic deduction for part of this expense would result in a modest tax cost in relation to its foreign income. It is of course impossible to include the R\&D expense of all of the losers in the allocation. Furthermore, there are important increases in value not explicable by any application of inputs. That is what an increase in U.S. total factor productivity means.

Mandatory cost sharing agreements would magnify the significance of all the current problems with cost sharing agreements, particularly the "buy in" issue. It would bring back all the disputes on the amount of required $R \& D$ allocations in the application of 
Section $861-8$ in the present system. Cost sharing agreements are often integral to the complex tax planning structures that have become the focus of recent concern. In view of all these complications, having fewer cost sharing agreements rather than more would seem desirable.

\section{CONCLUSIONS}

We evaluate a series of proposals for the reform of the U.S. system of taxing crossborder corporate income, including (1) dividend exemption, (2) full current inclusion (the repeal of deferral), (3) a Japanese type of dividend exemption with a per-country effective tax rate test subject to an exception for an active business, (4) repeal of checkthe-box, and (5) four different versions of a minimum tax on foreign income: (a) a percountry minimum tax with dividend exemption, (b) a per-country minimum tax with dividend exemption, no active business exception, but a current deduction against the minimum tax base for real investment in the location, (c) a minimum tax at the overall foreign level at a higher rate, and (d) an overall minimum tax with expensing of current investment against the taxable U.S. base.

To compare these schemes with current law, we first reevaluate the burden of the dividend repatriation tax using evidence from the response to the 2005 repatriation tax holiday. We find that the implicit cost of avoiding repatriations is higher than found in previous estimates, particularly for high tech profitable foreign businesses, and rises as untaxed deferrals accumulate.

We simulate the effect of the various alternatives on effective tax rates for investment in high- and low-tax countries, with emphasis on the importance of parent-developed intangibles and their role in shifting income from the United States.

Our analysis demonstrates that it is possible to make improvements to the system of taxing cross-border income across many dimensions including reducing the lockout effect, reducing income shifting, reducing distortions of the choice of location, and reducing complexity. The goals are not necessarily in conflict. Compared to the other schemes, we find that the per-country minimum tax with expensing for real investment has many advantages with respect to these margins. The per-country minimum tax offsets the increased incentives for income shifting under pure dividend exception and is better than full inclusion in tailoring companies' effective tax rates to their competitive position abroad. No U.S. tax burden will fall on companies that earn just a normal return abroad. The per-country minimum tax is basically a tax on large excess returns in low-tax locations, cases in which the company probably has less intense foreign competition.

Unlike the Japanese type of dividend exemption alternative, the minimum tax does not contain a cliff in which the income is subject to the full home country rate if it fails the minimum tax and active business tests. Under the minimum tax with no cliff, the company has more of an incentive to lower foreign taxes, for example by using checkthe-box to ship income to a tax haven, and will often prefer paying the U.S. minimum tax to paying a higher foreign tax. Finally, the per-country minimum tax seems more advantageous than the repeal of check-the-box. It is more effective in discouraging 
income shifting and raising the effective tax rate in low-tax countries. There was substantial income shifting before check-the-box. Further, repeal of check-the-box results in a cliff with respect to income shifted to tax havens through the use of hybrid entities. As a result, companies would unwind their hybrids and prefer to pay the generally lower host country rates rather than the full U.S. rate. The United States would pick up that revenue under the minimum tax.

In summary, the minimum tax with expensing combines the advantages of the extreme alternatives, dividend exemption and full inclusion, and reduces their shortcomings. In addition, the overall minimum tax seems a serious alternative deserving consideration. While it is not as successful as the per-country minimum tax in targeting tax haven income, it is a substantial move in that direction and is much simpler. Earnings and tax do not have to be split up by country, which requires looking through hybrid entities to determine where income is actually subject to tax. If an allowance is given under the minimum tax for acquisitions, as we recommend to equalize the treatment of greenfield and brownfield investments, this is particularly complex under the percountry version because the target's price would frequently have to be divided among different jurisdictions.

Our evaluation of alternatives to reform also considers other options including formula apportionment, taxing income in the jurisdiction in which consumers reside, and mandatory cost sharing agreements for R\&D. None of these seem to be attractive alternatives as their flaws greatly outweigh their benefits.

\section{ACKNOWLEDGEMENTS}

Nothing in this paper should be construed as reflecting the views and policy of the U.S. Treasury Department. We are very grateful to Ralph Rector for advice and very useful tabulations of the Treasury tax files and to Siobhan O'Keefe for excellent research assistance. We thank Alan Auerbach, Michael Devereux, Patrick Driessen, Edward Kleinbard, Timothy McDonald, Michael Mundaca, Paul Oosterhuis, John Samuels, Stephen Shay, Martin Sullivan, Philip West, and participants at the New York University School of Law Tax Policy Colloquium and the Oxford Centre for Business Taxation Annual Symposium for helpful comments on an earlier draft.

\section{REFERENCES}

Allen, Eric J., and Susan C. Morse, 2013. "Tax Haven Incorporation for U.S.-Headquartered Firms: No Exodus Yet." National Tax Joumal 66 (2), 395-420.

Altshuler, Rosanne, and Harry Grubert, 2001. "Where Will They Go if We Go Territorial? Dividend Exemption and the Foreign Location Decisions of U.S. Multinational Corporations." National Tax Journal 54 (4), 787-809.

Altshuler, Rosanne, and Harry Grubert, 2002. "Repatriation Taxes, Repatriation Strategies, and Multinational Financial Policy." Journal of Public Economics 87 (1), 73-107. 
Altshuler, Rosanne, and Harry Grubert, 2010. "Formula Apportionment: Is it Better than the Current System and are there Better Alternatives?" National Tax Journal 63 (4), 1145-1184.

Arulampalam, Wiji, Michael P. Devereux, and Federica Liberini, 2012."Taxes and the Location of Targets." Working Paper 1213. Oxford University Centre for Business Taxation, Oxford, UK.

Avi-Yonah, Reuven S., and Kimberly A. Clausing, 2007. "Reforming Corporate Taxation in a Global Economy: A Proposal to Adopt Formulary Apportionment." Hamilton Project Discussion Paper:-The Brookings Institution; Washington, DC.

Clausing, Kimberly,.2009. "Multinational Firm Tax Avoidance and Tax Policy." National Tax Journal 62 (4), 703-725.

Desai, Mihir A., C. Fritz Foley, and James R. Hines Jr., 2001. "Repatriation Taxes and Dividend Distortions." National Tax Journal 54 (4), 829-851.

Devereaux, Michael P., Christina Elschner, Dieter Endres, and Christoph Spengel, 2009. "Effective Tax Rates Using the Devereux-Griffith Methodology." ZEW Center for European Economic Research, Mannheim, Germany.

Graetz, Michael J., and Paul W. Oosterhuis, 2001. "Stucturing an Exemption System for Foreign Income of U.S. Corporations." National Tax Journal 54 (3), 771-786.

Grubert, Harry, 2005. "Tax Credits, Source Rules, Trade, and Electronic Commerce: Behavioral Margins and the Design of International Tax Systems." Tax Law Review 58 (2), 149-190.

Grubert, Harry, 2012. "Foreign Taxes and the Growing Share of Multinational Company Income Abroad: Profits, Not Sales, Are Being Globalized." National Tax Journal 65 (2), 247-282.

Grubert, Harry, and Rosanne Altshuler, 2008. "Corporate Taxes in the World Economy: Reforming the Taxation of Cross-Border Income." In Diamond, John W., and George R. Zodrow (eds.), Fundamental Tax Reform: Issue, Choices, and Implications, 319-354. MIT Press, Cambridge, MA.

Grubert, Harry, and John Mutti, 1995. "Taxing Multinationals in a World with Portfolio Flows and R\&D: Is Capital Export Neutrality Obsolete?" International Tax and Public Finance 2 (3), $439-457$.

Grubert, Harry, and John Mutti, 2001. Taxing International Business Income: Dividend Exemption versus the Current System. American Enterprise Institute, Washington, DC.

Huizinga, Harry P., and Johannes Voget, 2009. "International Taxation and the Direction and Volume of Cross-border M\&As." Journal of Finance 64 (3), 1217-1249.

Kleinbard, Edward D., 2011. "Stateless Income." Florida Tax Review 11 (9), 699-774.

President's Economic Recovery Advisory Board, 2010. "The Report on Tax Reform Options: Simplification, Compliance, and Corporate Taxation." U.S. Government Printing Office, Washington, DC. 
Redmiles, Melissa, 2008. "The One-Time Received Dividend Deduction." Internal Revenue Service Statistics of Income Bulletin, Spring, 102-114.

Shaviro, Daniel, 2011. "The David R. Tillinghast Lecture: The Rising Tax-Electivity of U.S. Corporate Residence." Tax Law Review 64 (3), 101-154.

U.S. House Ways and Means Committee, 2011. "Discussion Draft to Amend the Internal Revenue Code of 1986 to Provide for Comprehensive Income Tax Reform," Washington, DC, http:// waysandmeans.house.gov/uploadedfiles/discussion_draft.pdf.

Voget, Johannes, 2011. "Relocation of Headquarters and International Taxation." Journal of Public Economics 95 (9-10), 1067-1081.

Yorgason, Daniel R., 2007. "Research and Development Activities of U.S. Multinational Companies." Survey of Current Business 87. (3), 22-39. 
Copyright of National Tax Journal is the property of National Tax Association and its content may not be copied or emailed to multiple sites or posted to a listserv without the copyright

holder's express written permission. However, users may print, download, or email articles for individual use. 